\title{
Evaluation of botanicals and bioagents against chickpea wilt complex pathogens
}

\author{
P.S. MORE* AND R.L. PARATE \\ Department of Plant Pathology, College of Agriculture (Dr.P.D.K.V.) NAGPUR (M.S.) INDIA
}

\begin{tabular}{ll} 
ARITCLE INFO \\
\hline Received $:$ & 28.04 .2016 \\
Revised $:$ & 19.08 .2016 \\
Accepted & $: 03.09 .2016$
\end{tabular}

\section{KEY WORDS :}

Chickpea, Fusarium oxysporum f. sp. ciceri, Rhizoctonia bataticola, Sclerotium rolfsii, Leaf extract

\begin{abstract}
Botanicals and bioagents were evaluated by following poison food technique and dual culture technique against three pathogens. Data indicate significant difference on mean colony diameter at all the internal over uninoculated control. Fungicides carbendazim treatment recorded 100 per cent growth inhibition against Fusarium oxysporum f.sp. ciceri, Rhizoctonia bataticola, Sclerotium rolfsii. Among botanicals Azadirachta indica at 20 per cent conc. Inhibits 84.44 per cent growth of Fusarium oxysporum $\mathrm{f}$. sp. ciceri, 85.22 per cent growth of Rhizoctonia bataticola and 85.55 per cent growth of Sclerotium rolfsii. Trichoderma viride found most effective for restricting mycelial growth of Fusarium oxysporum f. sp ciceri. Pseudomonas fluorescens found most effective for inhibiting mycelial growth of Rhizoctonia bataticola. In case of Sclerotium rolfsii, Trichoderma harzianum was found most effective.
\end{abstract}

How to view point the article : More, P.S. and Parate, R.L. (2016). Evaluation of botanicals and bioagents against chickpea wilt complex pathogens. Internat. J. Plant Protec., 9(2) : 469473, DOI : 10.15740/HAS/IJPP/9.2/469-473. 